\title{
TANTALUM-BASED COATINGS ON STAINLESS STEEL FOR FUEL-CELL BIPOLAR PLATES
}

\author{
Jakub LUDVÍK, Tomáš LOVAŠı, Zuzana ŽOFKOVÁ, Milan KOUŘIL \\ University of Chemistry and Technology Prague, Department of Metals and Corrosion Engineering, Prague, \\ Czech Republic, EU, Jakub.Ludvik@vscht.cz
}

https://doi.org/10.37904/metal.2020.3536

\begin{abstract}
Stainless steels are promising materials for fuel cell bipolar plates. It meets high demands for bipolar plates, good thermal and electrical conductivity, low cost, good mechanical properties. However, corrosion stability in fuel cell environment is either poor or achieved by passive layer. Passive layer improves corrosion resistance, but decrease electrical conductivity, respectively increase contact resistance. Coating stainless steel is one approach, how to obtain suitable material. This study focused on commonly used stainless steel AISI 316L as reference and two Ta-based coatings, tantalum coating and tantalum coating with upper layer of $\mathrm{Ta}_{2} \mathrm{O}_{5}$ and $\mathrm{RuO}_{2}$. All materials were tested in simulated PEMFC environment, diluted sulfuric acid of $\mathrm{pH} 3$ with $1 \mathrm{ppm}$ fluoride ions at $80^{\circ} \mathrm{C}$. Open circuit potential, linear sweep voltammetry anodic and cathodic dynamic scans were carried out. Materials were compared only based on short-term electrochemical measurements. Despite that, tantalum coating perform better corrosion resistance than bare steel, passive layer of tantalum is non-conductive, thus inappropriate for fuel cells. Tantalum coating with oxide upper layer cannot be compared based on short-term electrochemical measurements.
\end{abstract}

Keywords: Bipolar plates, corrosion, coated stainless steel

\section{INTRODUCTION}

Proton exchange membrane fuel cell (PEMFC) is supposed to be an alternative to combustion engines. Technology of converting chemical energy from reaction between hydrogen and oxygen into electrical energy has many advantages as low emission, low operating temperatures and relatively high-energy efficiency $[1,2]$. Disadvantages of PEMFCs are big volume and weight of cell construction, mainly due to bipolar plates. Also cost of membrane, catalyst and bipolar plates make this technology too expensive for wider use. Parameters such as volume, weight and acquisition cost must be reduced, especially for automotive industry [3]. PEM fuel cell consist of bipolar plates (BP) and membrane electron assembly (MEA), which contain gas diffusion layer (GDL), catalyst, membrane and sealing. Bipolar plates has to fulfil lot of requirements, good electrical and thermal conductivity, chemical stability, hydrophobicity and others. This multifunctionality is hardly accomplished. Most of BP are made of graphite, to a lesser extend of graphite-polymer composites [4]. Graphite excel in chemical stability, thermal and electrical conductivity, but suffer for its poor mechanical properties. Graphite bipolar plates are heavy, bulky, fragile and manufacturing process is difficult and expensive $[4,5]$. As a potential alternative for graphite seem promising metallic bipolar plates. As for metals mostly considered are stainless steel, titanium, nickel, copper, aluminium and their alloys. New material for bipolar plates should meet parameters given by US Department of Energy (DOE) Table 1 [6], DOE also define parameters of measurements. Stainless steels seems most promising, especially for portable and automotive applications. It has great thermal and electrical conductivity, gas impermeability, excellent mechanical properties and formability [4]. Unfortunately, corrosion resistance in fuel cell environment is main problem of stainless steels. PEMFC operating conditions are around $80^{\circ} \mathrm{C}$, high humidity and acidic character $(\mathrm{pH} 2-3)$. Corrosion of stainless steel release ions, which block membrane exchange capacity and lower the fuel cell 
performance. Other problem of metallic bipolar plates is interfacial contact resistance (ICR), which goes against corrosion resistance in most cases [7]. The more corrosion resistant stainless steel, the bigger ICR it has. ICR is tightly connected with passive layer. Thickness and chemical composition of passive layer influence ICR significantly. Bare stainless steels seems inadequate based on those parameters. However, proper coating on stainless steel can solve this [8]. There is more approach to coating, like carbon, carbides, nitrides, conductive polymers, metallic coatings, noble metals and their multilayer combinations. Coatings can be prepared by PVD or CVD technology (e.g. magnetron sputtering, ion arc plating) [1,7]. Corrosion resistance and ICR depends than on quality of coating, which corresponds also with surface condition of steel [9]. Even there are plenty variations of coating combinations and preparation methods, coatings improve corrosion resistance and lower ICR in PEMFC environment in general. Nevertheless, coatings are susceptible to microstructural defects, thus multilayer coatings has lower risk of defect that goes through all layers $[10,11]$.

Table 1 DOE limits for 2020 [6]

\begin{tabular}{|c|c|c|}
\hline Monitored property & 2020 Objectives & Notes \\
\hline Cost & $\leq 3 \$ \cdot \mathrm{kW}^{-1}$ & $500,00080-\mathrm{kW}_{\text {net }}$ systems per year \\
\hline Plate weight & $0.4 \mathrm{~kg} \cdot \mathrm{kW}^{-1}$ & - \\
\hline Corrosion rate (anode) & $<1 \mu \mathrm{A} \cdot \mathrm{cm}^{-2}$ & $\begin{array}{c}\mathrm{pH} 30.1 \mathrm{ppm} \mathrm{HF}, 80^{\circ} \mathrm{C} \text {, peak active current } \\
<1 \times 10^{6} \mathrm{~A} \cdot \mathrm{cm}^{-2} \text { (potentiodynamic test at } 0.1 \mathrm{mV} \cdot \mathrm{s}^{-1}, \\
-0.4 \mathrm{~V} \text { to }+0.6 \mathrm{~V}(\mathrm{Ag} \text { vs. } \mathrm{AgCl}) \text { ), de-aerated with } \mathrm{Ar} \text { purge. }\end{array}$ \\
\hline Corrosion rate (cathode) & $<1 \mu \mathrm{A} \cdot \mathrm{cm}^{-2}$ & $\begin{array}{c}\mathrm{pH} 30.1 \mathrm{ppm} \mathrm{HF}, 80^{\circ} \mathrm{C} \text {, passive current } \\
<5 \times 10^{8} \mathrm{~A} \cdot \mathrm{cm}^{-2} \text { (potentiostatic test at }+0.6 \mathrm{~V}(\mathrm{Ag} \text { vs. } \mathrm{AgCl}) \text { for } \\
>24 \mathrm{~h} \text {, aerated solution. }\end{array}$ \\
\hline Electrical conductivity & $>100 \mathrm{~S} \cdot \mathrm{cm}^{-1}$ & \\
\hline Areal specific resistance & $<0.01 \mathrm{ohm} \cdot \mathrm{cm}^{2}$ & $\begin{array}{l}\text { Includes interfacial contact resistance (on as received and } \\
\text { after potentiostatic test) at } 138 \mathrm{~N} \cdot \mathrm{cm}^{-2}\end{array}$ \\
\hline Flexural strength & $>25 \mathrm{MPa}$ & ASTM-D 790-10 \\
\hline Forming elongation & $40 \%$ & ASTM E8M-01 \\
\hline Plate $\mathrm{H}_{2}$ permeation coefficient & $<1.3 \cdot 10^{-14} \mathrm{~cm}^{3}$ & ASTM D1434, $80^{\circ} \mathrm{C}, 3 \mathrm{~atm}, 100 \% \mathrm{RH}$ \\
\hline
\end{tabular}

\section{EXPERIMENT}

\subsection{Tested materials and simulating electrolyte}

For this work was chosen stainless steel AISI $316 \mathrm{~L}$ as reference material and two types of coatings prepared on this steel to compare. First one is pure tantalum and second is tantalum with upper layer of $\mathrm{Ta}_{2} \mathrm{O}_{5}$ and $\mathrm{RuO}_{2}$. Both coating were prepared by CVD technology. Thickness of the coatings was $20-50 \mu \mathrm{m}$. Samples were thin sheet $30 \mathrm{~mm} \times 50 \mathrm{~mm}$. Bare $316 \mathrm{~L}$ was treated before measurements by grinding paper P1200, rinsed with water, ethanol and dried. Coated samples were only washed and dried.

Table 2 Main alloying elements of stainless steel 316L

\begin{tabular}{|c|c|c|c|c|c|}
\hline Element (wt. \%) & C & Cr & Ni & Mo & Mn \\
\hline AISI 316L & $<0.03$ & $16-18$ & $10-12$ & $2-2.5$ & $<2$ \\
\hline
\end{tabular}

For each set of measurements was prepared fresh solution simulating PEMFC environment. Solution was prepared by mixing $1 \mathrm{ml}$ of $0.01 \%$ hydrofluoric acid and distilled water to $1 \mathrm{I}$. Then was modified the $\mathrm{pH}$ of the solution to value of 3 by using $\left.1 \mathrm{~mol} \cdot\right|^{-1}$ sulfuric acid. 


\subsection{Electrochemical measurement}

Measurements were done in corrosion cell with lateral sample deposition. Solution was heated to $80^{\circ} \mathrm{C}$ using thermostat. Experiment was set up for 3-electrode arrangement, using saturated argent-chloride reference electrode, platinum wire as counter electrode and sample as working electrode. This arrangement was used for all electrochemical measurements, open circuit potential, polarization resistance, cathodic and anodic polarizations. Experiments were carried out on Zahner Zennium electrochemical workstation and repeated at least twice to eliminate errors and ensure reproducibility of the experiment. Data were than evaluated in Thales XT Analysis. Solution simulating PEMFC environment was used only once for a sequence of measurements, consisting of open circuit potential, followed by polarization resistance and dynamic scan (cathodic or anodic). Open circuit potential was measured for $3600 \mathrm{~s}$. Immediately followed by polarization resistance ranged from $-25 \mathrm{mV}$ vs. OCP to $+25 \mathrm{mV}$ vs. OCP with scan rate of $0.1 \mathrm{mV} \cdot \mathrm{s}^{-1}$. Cathodic dynamic scan set up ranged from $+100 \mathrm{mV}$ vs. OCP to $-2 \mathrm{~V}$ vs. ACLE, anodic part ranged from $-100 \mathrm{mV}$ vs. OCP to $+2 \mathrm{~V}$ vs. ACLE with $5 \mathrm{mV} \cdot \mathrm{s}^{-1}$ scan rate. During all measurements was the solution deaerated using nitrogen.

\section{RESULTS AND DISCUSION}

Before experiment metallographic cross-sections of both coatings were pictured by SEM (Tescan Vega 3). Figure 1 shows different thickness, bare tantalum coating has 40-50 micrometers, tantalum with oxide upper layer around 20-25 micrometers. Both layers are uniform and defect-free, despite that surface of bare tantalum is more rugged.

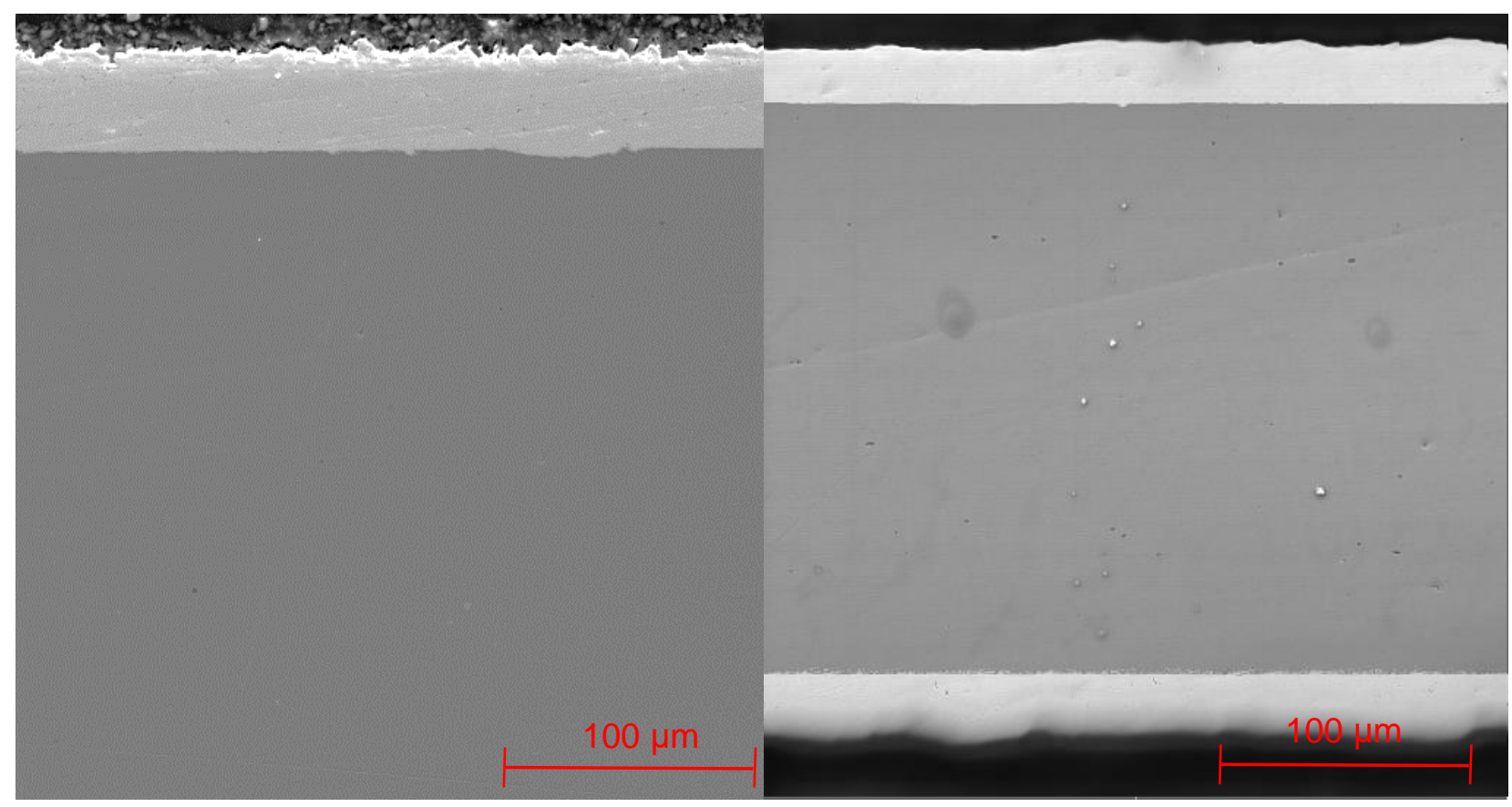

Figure 1 Cross-section of coatings, tantalum (left) and tantalum with $\mathrm{Ta}_{2} \mathrm{O}_{5}$ and $\mathrm{RuO}_{2}$ upper layer (right)

After electrochemical measurements in simulated PEMFC solution, corrosion indicators were evaluated using Thales XT Analysis. Figure 2 shows anodic parts of polarization, bare steel corrode in passive state, same as tantalum coated steel. Curve of tantalum coating with oxide upper layer does not reflect corrosion reaction of the coating, but chemical reaction of the solution. Cathodic parts at (Figure 3) show reduction of residual oxygen and hydrogen depolarization. Curves were fitted and all data are summarized in Table 3. 


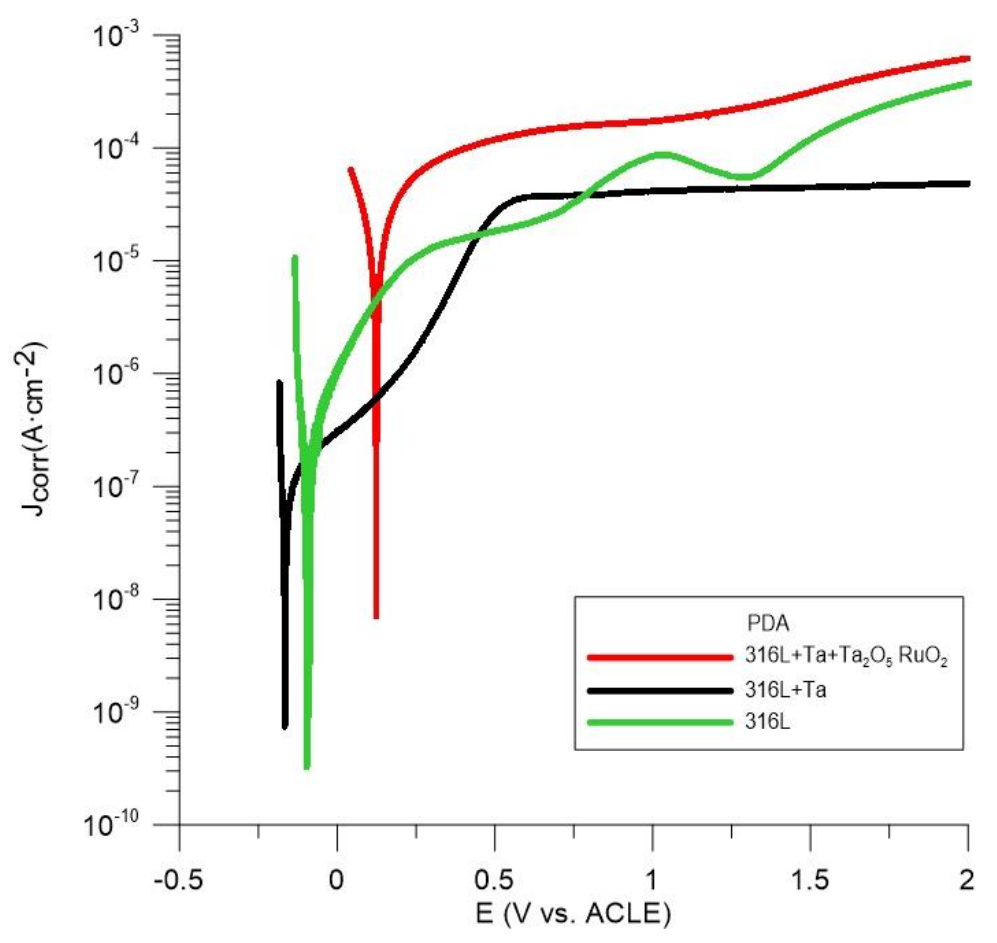

Figure 2 Anodic polarizations in diluted $\mathrm{H}_{2} \mathrm{SO}_{4}\left(\mathrm{pH} 3,1 \mathrm{ppm} \mathrm{HF}, 80^{\circ} \mathrm{C}\right.$, deaerated by $\left.\mathrm{N}_{2}\right)$ range $-100 \mathrm{mV}$ vs. OCP to $+2 \mathrm{~V}$ vs. ACLE with scan rate $5 \mathrm{mV} \cdot \mathrm{s}^{-1}$

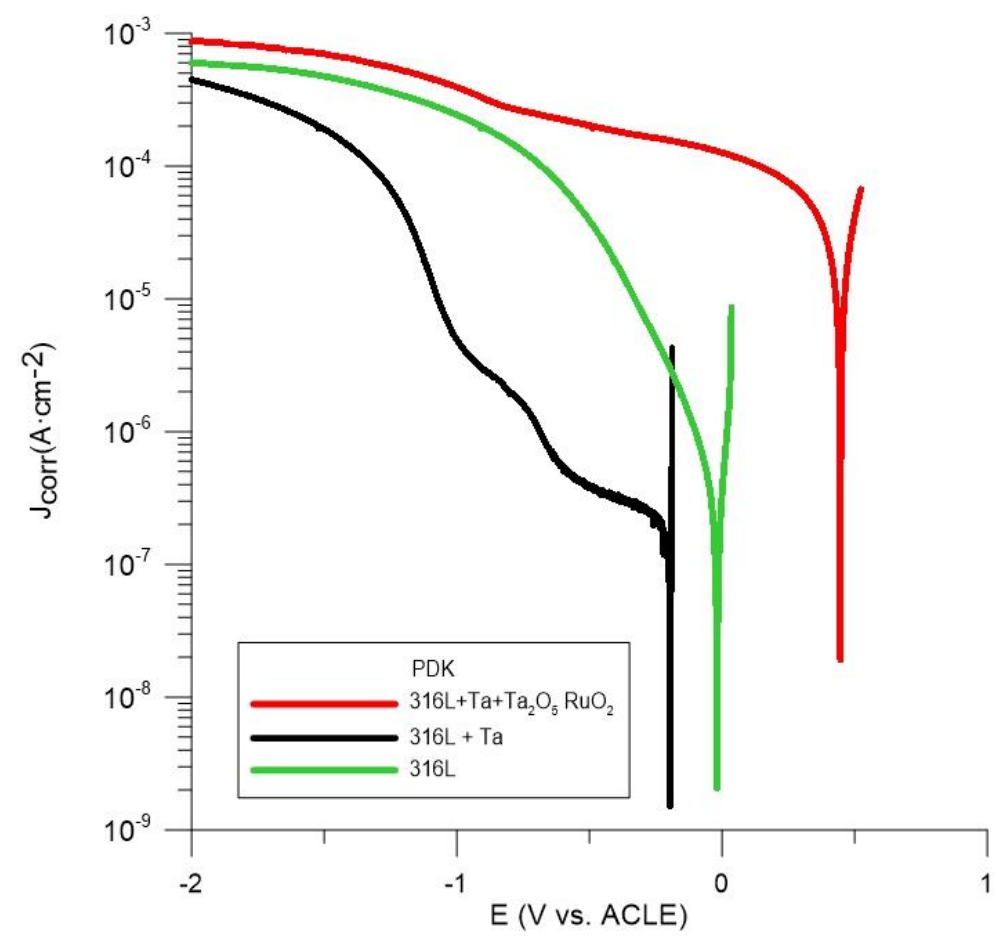

Figure 3 Cathodic polarizations in diluted $\mathrm{H}_{2} \mathrm{SO}_{4}\left(\mathrm{pH} 3,1 \mathrm{ppm} \mathrm{HF}, 80^{\circ} \mathrm{C}\right.$, deaerated by $\left.\mathrm{N}_{2}\right)$ range $-100 \mathrm{mV}$ vs. OCP to $+2 \mathrm{~V}$ vs. ACLE with scan rate $5 \mathrm{mV} \cdot \mathrm{s}^{-1}$

Comparing $316 \mathrm{~L}$ and tantalum coated $316 \mathrm{~L}$ the coating improves corrosion parameters. Higher polarization resistance and lower corrosion current density result in lower corrosion rates. Anodic Tafel slope also indicates better passive behavior of tantalum coating. The part of curve at (Figure 2) from 0.5 to $2 \mathrm{~V}$ vs. ACLE indicates non-conductive layer, which would not have to be beneficial for fuel cells. 
Table 3 Electrochemical parameters of $316 \mathrm{~L}$ and Ta-based coatings

\begin{tabular}{|c|c|c|c|c|c|c|}
\hline Material & $\mathbf{R p}\left(\mathbf{\Omega} \cdot \mathbf{m}^{2}\right)$ & $\begin{array}{c}\mathbf{E}_{\text {corr }} \\
(\mathbf{m V} \mathbf{v s .} \mathbf{A C L E})\end{array}$ & $\boldsymbol{\mu A} \cdot \mathbf{c m}^{-2}$ & $\boldsymbol{\mu A} \cdot \mathbf{c m}^{-2}$ & $\boldsymbol{\beta}_{\mathbf{a}}(\mathbf{m V} / \mathbf{d e c a d e})$ & $\mathbf{B}_{\mathbf{c}}(\mathbf{m V} / \mathbf{d e c a d e})$ \\
\hline $316 \mathrm{~L}$ & 13.1 & -159 & 0.482 & 0.245 & 237 & -251 \\
\hline $316 \mathrm{~L}+\mathrm{Ta}$ & 26.0 & -313 & 0.054 & 0.034 & 328 & -238 \\
\hline $316 \mathrm{LTa}+\mathrm{Ta}_{2} \mathrm{O}_{5}+\mathrm{RuO}_{2}$ & 0.6 & 348 & 2.200 & 3.983 & 511 & -571 \\
\hline
\end{tabular}

\section{CONCLUSION}

This study compares stainless steel $316 \mathrm{~L}$ and two Ta-based coatings, bare tantalum and tantalum with oxide upper layer in simulated PEMFC environment. Simulating solution is diluted sulfuric acid with $\mathrm{pH} 3$ and $1 \mathrm{ppm}$ of fluoride ions at $80^{\circ} \mathrm{C}$. Tantalum coating seems not suitable for fuel cells, it is corrosive resistant, but its passive layer is non-conductive. Tantalum coating with oxide upper layer is interesting, high electrochemical activity of electrolyte, oxygen and hydrogen is expected due to conductive, corrosion resistant $\mathrm{RuO}_{2}$. Its properties and behaving cannot be assessed based on those short-term measurements. Contact resistance measurements, long-term exposure along with leachate analysis have to be done.

\section{ACKNOWLEDGEMENTS}

\section{This article was created with support of EC CZ.02.1.01/0.0/0.0/16_025/0007414 PaC-NG Fuel Cells with Low Platinum Content (2018-22)}

\section{REFERENCES}

[1] ASRI, N.F., HUSAINI, T., SULONG, A.B., MAJLAN, E.H., DAUD, W.R.W. Coating of stainless steel and titanium bipolar plates for anticorrosion in PEMFC: A review. International Journal of Hydrogen Energy. 2017, vol. 42, no. 14, pp. 9135-9148.

[2] TAHERIAN, R. A review of composite and metallic bipolar plates in proton exchange membrane fuel cell: Materials, fabrication and material selection. Journal of Power Sources. 2014, vol. 265, pp. 370-390.

[3] LENG, Y., MING, P., YANG, D., ZHANG, C. Stainless steel bipolar plates for proton exchange membrane fuel cells: Materials, Flow channel design and forming processes. Journal of Power Sources. 2020, vol. 451, pp. 227783.

[4] ALO, O.A., OTUNNIYI, I.O., PIENAAR, HCvZ., IYUKE, S.E. Materials for bipolar plates in polymer electrolyte membrane fuel cell: Performance criteria and current benchmarks. Procedia Manufacturing. 2017, vol. 7, pp. 395401.

[5] U.S. DEPARTMENT OF ENERGY: ENERGY EFFICIENCY \& RENEWABLE ENERGY. Harvard British Standard: Referencing Guide [online]. [viewed 2019-9-25]. Available from: https://www.energy.gov/eere/fuelcells/doetechnical-targets-polymer-electrolyte-membrane-fuel-cell-components.

[6] ANTUNES, R.A., OLIVEIRA, M.C.L., ETT, G., ETT, V. Corrosion of metal bipolar plates for PEM fuel cells: A review. International Journal of Hydrogen Energy. 2010, vol. 35, no. 8, pp. 3632-3647.

[7] ZHANG, D., WANG, Z., HUANG, K. Composite coating with in situ formation for Fe-Ni-Cr alloys as bipolar plate of PEMFC. International Journal of Hydrogen Energy. 2013, vol. 38, no. 26, pp. 11379-11391.

[8] YANG, M., ZHANG, D. Effect of surface treatment on the interfacial contact resistance and corrosion resistance of Fe-Ni-Cr alloy as a bipolar plate for polymer electrolyte membrane fuel cells. Energy. 2014, vol. 64, pp. $242-247$.

[9] WANG, S., HOU, M., ZHAO, Q., JIANG, Y., WANG, Z., LI, H., FU, Y., SHAO, Z. Ti/(Ti,Cr)N/CrN multilayer coated 316Lstainless steel by arc ion plating as bipolar plates for proton exchange membrane fuel cells. Journal of Energy Chemistry. 2017, vol. 26, no. 1, pp. 168-184.

[10] YI, P., PENG, L., ZHOU, T., WU, H., LAI, X. Cr-N-C multilayer film on 316L stainless steel as bipolar plates for proton exchange membrane fuel cells using closed field unbalanced magnetron sputter ion plating. International Journal of Hydrogen Energy. 2013, vol. 38, no. 3, pp. 1535-1543. 